Article

\title{
Increased Urinary 3-Mercaptolactate Excretion and Enhanced Passive Systemic Anaphylaxis in Mice Lacking Mercaptopyruvate Sulfurtransferase, a Model of Mercaptolactate-Cysteine Disulfiduria
}

\author{
Noriyuki Akahoshi, Tatsuro Minakawa, Masashi Miyashita, Uran Sugiyama, Chihiro Saito, \\ Rintaro Takemoto, Akihiro Honda, Waka Kamichatani, Shotaro Kamata, Yasumi Anan and \\ Isao Ishii *(D) \\ Department of Health Chemistry, Showa Pharmaceutical University, Machida, Tokyo 194-8543, Japan; \\ akahoshi@ac.shoyaku.ac.jp (N.A.); a14098@ug.shoyaku.ac.jp (T.M.); a14099@ug.shoyaku.ac.jp (M.M.); \\ a15070@ug.shoyaku.ac.jp (U.S.); b15055@ug.shoyaku.ac.jp (C.S.); a13082@ug.shoyaku.ac.jp (R.T.); \\ a14089@ug.shoyaku.ac.jp (A.H.); kajiwara@ac.shoyaku.ac.jp (W.K.); kamata@ac.shoyaku.ac.jp (S.K.); \\ ananya@ac.shoyaku.ac.jp (Y.A.) \\ * Correspondence: isao-ishii@umin.ac.jp; Tel.: +81-42-721-1563
}

Received: 23 December 2019; Accepted: 25 January 2020; Published: 27 January 2020

\begin{abstract}
Mercaptopyruvate sulfurtransferase (Mpst) and its homolog thiosulfate sulfurtransferase (Tst $=$ rhodanese) detoxify cyanide to thiocyanate. Mpst is attracting attention as one of the four endogenous hydrogen sulfide $\left(\mathrm{H}_{2} \mathrm{~S}\right)$ /reactive sulfur species (RSS)-producing enzymes, along with cystathionine $\beta$-synthase (Cbs), cystathionine $\gamma$-lyase (Cth), and cysteinyl-tRNA synthetase 2 (Cars2). MPST deficiency was found in 1960s among rare hereditary mercaptolactate-cysteine disulfiduria patients. Mpst-knockout $(\mathrm{KO})$ mice with enhanced liver Tst expression were recently generated as its model; however, the physiological roles/significances of Mpst remain largely unknown. Here we generated three independent germ lines of Mpst-KO mice by CRISPR/Cas9 technology, all of which maintained normal hepatic Tst expression/activity. Mpst/Cth-double knockout (DKO) mice were generated via crossbreeding with our previously generated $\mathrm{Cth}-\mathrm{KO}$ mice. Mpst-KO mice were born at the expected frequency and developed normally like $\mathrm{Cth}-\mathrm{KO}$ mice, but displayed increased urinary 3-mercaptolactate excretion and enhanced passive systemic anaphylactic responses when compared to wild-type or Cth-KO mice. Mpst/Cth-DKO mice were also born at the expected frequency and developed normally, but excreted slightly more 3-mercaptolactate in urine compared to Mpst-KO or Cth-KO mice. Our Mpst-KO, Cth-KO, and Mpst/Cth-DKO mice, unlike semi-lethal Cbs-KO mice and lethal Cars2-KO mice, are useful tools for analyzing the unknown physiological roles of endogenous $\mathrm{H}_{2} \mathrm{~S} / \mathrm{RSS}$ production.
\end{abstract}

Keywords: CRISPR/Cas9; cystathionine $\gamma$-lyase; hydrogen sulfide; mercaptolactate-cysteine disulfiduria; mercaptopyruvate sulfurtransferase; passive systemic anaphylaxis; reactive sulfur species; thiosulfate sulfurtransferase

\section{Introduction}

Mercaptolactate-cysteine disulfiduria (MCDU; OMIN 249650) is an autosomal recessive metabolic disorder that was first identified in the late 1960s [1]. A 47-year-old man, the product of a sibling mating, was severely mentally retarded and tended to have increased susceptibility to infection. He also excreted high concentrations of 3-mercaptolactate-cysteine disulfide ((2R)-2-amino-3-[(2-carboxy-2-hydroxyethyl) disulfanyl] propanoic acid; $\mathrm{C}(\mathrm{C}(\mathrm{C}=\mathrm{O}) \mathrm{O}) \mathrm{N}) \mathrm{SSCC}$ 
$(\mathrm{C}(=\mathrm{O}) \mathrm{O}) \mathrm{O})$ in his urine $[2,3]$. The dietary supplementation of cysteine (not methionine) to this patient caused a considerable increase in the urinary excretion of the disulfide in his urine [1,4], suggesting that his disorder was associated with cysteine metabolism. Later, mentally retarded [5] and mentally normal [6] MCDU patients were identified. At the time, MCDU was considered attributable to the deficiency of 3-mercaptopyruvate sulfurtransferase (Mpst) [5]. However, the incidence rate of MCDU is not known because it is not among the lists of the newborn screening or other routine clinical tests and experimental evidence for the onset of MCDU by Mpst deficiency has yet to be demonstrated. The first Mpst-knockout (KO) mice were generated by Nagahara et al. [7]. Unfortunately, their mice displayed unexpected overexpression of the evolutionarily- [8] and catalytically-related [9] enzyme thiosulfate sulfurtransferase (Tst; idiomatically known as rhodanese/rhodanase) which has Mpst activity [10], and their urine samples were not biochemically analyzed.

Mpst mediates the metabolism of 3-mercaptopyruvate (the deamination product of cysteine) and sulfite to pyruvate and thiosulfate [11], as well as the detoxification of cyanide $\left(\mathrm{CN}^{-}\right)$to thiocyanate $\left(\mathrm{SCN}^{-}\right)[12,13]$. Mpst is also a known anti-oxidant enzyme which regulates thioredoxin peroxidase activity $[8,14,15]$. However, the physiological significance of Mpst remains to be elucidated. As one of the four endogenous hydrogen sulfide $\left(\mathrm{H}_{2} \mathrm{~S}\right)$ /reactive sulfur species (RSS)-producing enzymes (along with cystathionine $\beta$-synthase [Cbs], cystathionine $\gamma$-lyase [Cth], and cysteinyl-tRNA synthetase 2 [Cars2]) [14,16-22], Mpst studies are now attracting attention as to their contribution to endogenous $\mathrm{H}_{2} \mathrm{~S} / \mathrm{RSS}$ production.

In the present study, we examined Mpst-KO mice produced using CRISPR/Cas9 technology. We preserved normal TST expression by minimizing the size of Mpst gene deletion and found that our mice display increased urinary excretion of 3-mercaptolactate and enhanced passive systemic anaphylaxis (PSA), while maintaining hepatic Tst expression/activity. Moreover, we also generated $\mathrm{Mpst} / \mathrm{C}$ th-double knockout (DKO) mice as a useful tool to investigate their mutually compensatory roles in mice.

\section{Results}

\subsection{Establishment of Three Independent Mpst Mutant Lines}

The CRISPR/Cas9 genome editing was used to delete exon 2 of Mpst which encodes $67 \%$ of the Mpst open reading frame (Figure 1A; and Supplementary Figure S1A for full DNA sequences) in one hundred C57BL/6J fertilized zygotes; from which 14 mice (9 males and 5 females) were born (14\% birthrate). The Mpst deletion was apparent in two females and single male as revealed by tail DNA PCR (Figure 1B) and confirmed by direct sequencing. The targeted region was deleted in the 1st and 3rd lines but a substantial portion of random DNA repair was found in the 2nd line (Supplementary Figure S1B-E). All three lines were successful in germline transmission. Mating of their progeny produced both heterozygous and homozygous $\mathrm{KO}$ mice (Het and $\mathrm{KO}$, respectively) as manifested by tail DNA PCR (Figure 1C). Mpst-Het and Mpst-KO mice were generally obtained with the expected frequency without marked sexual bias (Table 1). 

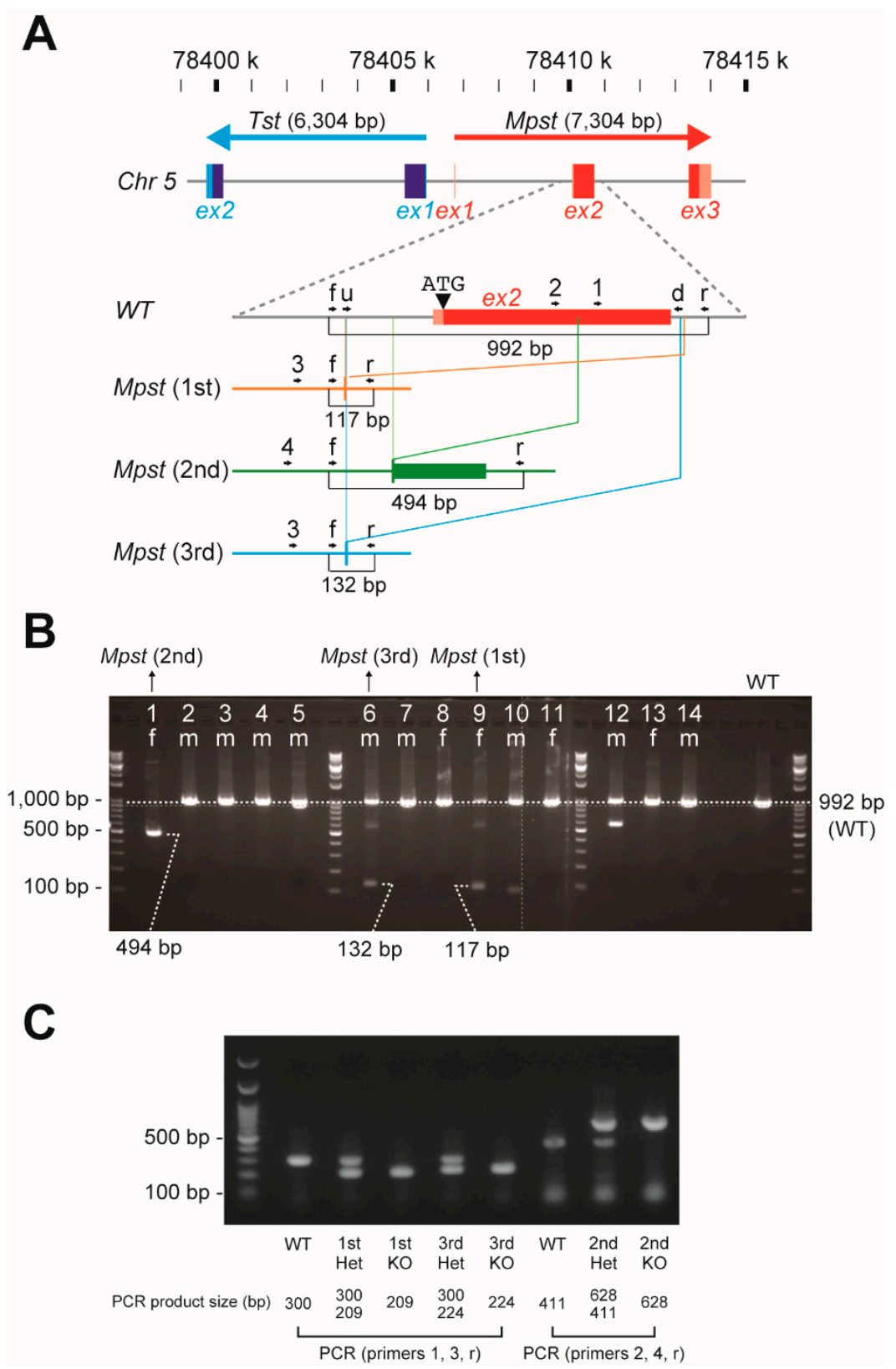

Figure 1. Mpst gene targeting in mice. (A) Outline for the Mpst gene deletion by CRISPR/Cas9 and production of 3 mutants. The 7304 bp mouse Mpst gene consists of 3 exons and is located proximal to its homolog Tst gene. The upstream $(\mathrm{u})$ and downstream $(\mathrm{d})$ crRNAs were designed to delete exon 2 which contains the start ATG codon and $67 \%$ of the entire open reading frame. Three independent mouse lines (1st, 2nd, and 3rd) were established. (B) Initial screening of 1st-3rd mouse lines from 14 independent mice ( 9 males and 5 females) that originated from individual fertilized zygotes electroporated with Cas9 protein, tracrRNA and crRNAs ( $u$ and d). PCR with forward (f) and reverse (r) primers detected the deletion of Mpst exon 2 in the 1st-3rd lines. (C) PCR detection of 1st and 3rd-type deletion using 1, 3 , and $\mathrm{r}$ primers and 2nd-type deletion using 2, 4, and r primers from tail DNAs of wild-type (WT), Mpst-heterozygous (Het), and Mpst-homozygous (KO) mutant mice. 
Table 1. Inheritance of the Mpst and Cth mutant alleles in mice.

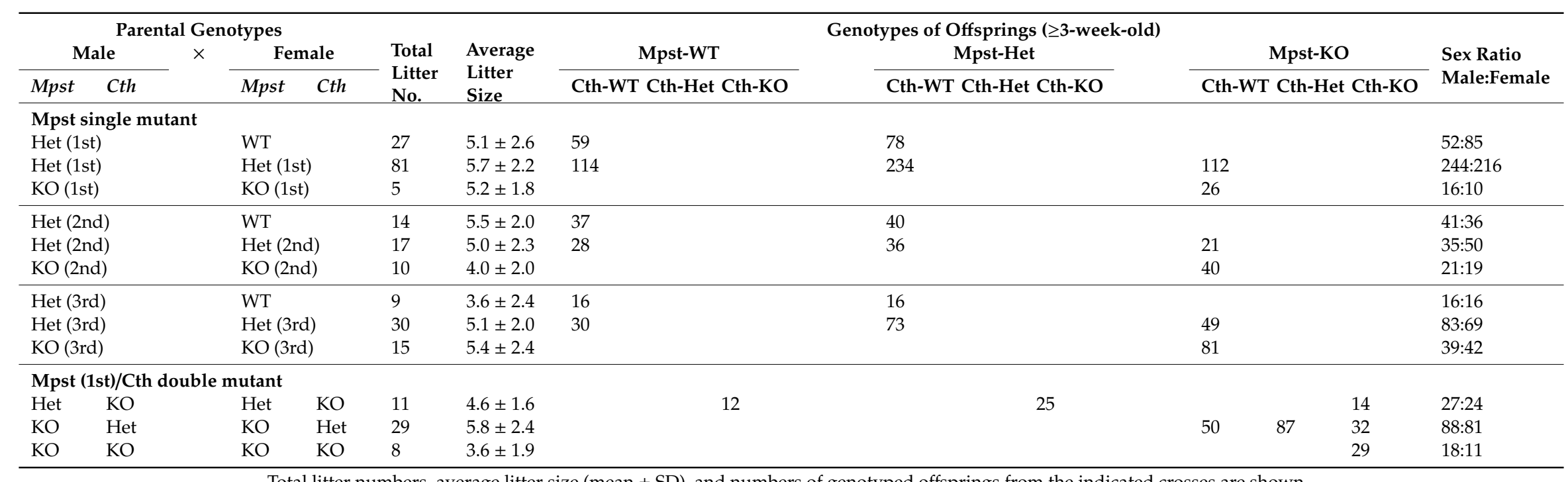

Total litter numbers, average litter size (mean $\pm \mathrm{SD}$ ), and numbers of genotyped offsprings from the indicated crosses are shown. 


\subsection{Mpst, Tst, Cbs, and Cth Expression in Mpst Mutant Livers}

We developed an anti-mouse Mpst rabbit polyclonal antibody by immunizing a rabbit with purified mouse full-length recombinant Mpst protein used in our assays. Mpst expression was widespread similar to its homolog Tst. All 26 mouse organs we tested expressed 33-kDa Mpst proteins (as well as 38-kDa Tst) to greater or lesser degrees. This is in stark contrast to the other two $\mathrm{H}_{2} \mathrm{~S} / \mathrm{RSS}$-producing enzymes, Cbs and Cth (Figure 2A). In all 3 germ lines, Mpst-Het livers displayed approximately $50 \%$ Mpst expression levels of wild-type (WT) livers. Mpst-KO livers did not express Mpst, as expected (Figure 2B). Therefore, the random DNA repair in the 2nd line (Supplementary Figure S1D) likely did not confer the expression of unexpected Mpst fragments. We found our Mpst antibody cross-reacts with 38-kDa Tst because pre-incubation of this antibody with recombinant Tst proteins abolished 38-kDa bands but not 33-kDa Mpst bands in the western analyses (Supplementary Figure S2). Using this antibody, we observed that hepatic Tst expression levels are not altered in all Mpst mutants (Figure 2B). Furthermore, Western blot analyses of liver proteins using a specific anti-Tst rabbit monoclonal (that does not cross-react with mouse Mpst), anti-Cbs rabbit polyclonal, anti-Cth mouse monoclonal, and anti-glutathione peroxidase 1 (Gpx1, another major anti-oxidant protein) antibodies, did not detect any significant differences for Tst, Cbs, Cth, Gpx1 expression within Mpst mutant mice (Figure 2C). Mpst and Tst are homologous proteins (63.5\% similarity cDNA, $57.6 \%$ similarity protein sequence). Further, Mpst has some Tst activity and Tst has some Mpst activity [9]. Indeed, in vitro Mpst and Tst enzyme assays using 3-mercaptopyruvate (3-MP) and thiosulfate as substrates revealed that Mpst recombinant protein has some Tst activity while Tst recombinant protein has some Mpst activity at high substrate concentrations (Figure 3A,B). However, at lower concentrations (5.95 mM 3-MP for Mpst and $25 \mathrm{mM}$ thiosulfate for Tst), both enzymes displayed specific activities (Figure 3A,B). At these reaction conditions and substrate concentrations, liver homogenates from Mpst mutant mice displayed specific Mpst and Tst activities that match well with their Mpst and Tst protein expression levels (Figure 3A,B).

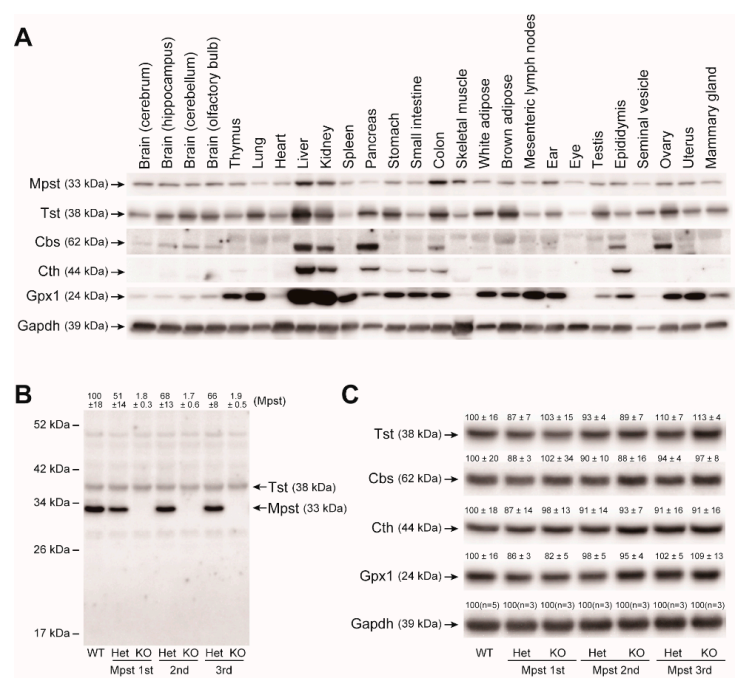

Figure 2. Tissue expression of mercaptopyruvate sulfurtransferase (Mpst) and related proteins in adult wild-type and Mpst mutant mice. All samples were taken from males except for the ovary, uterus, and mammary gland. (A) Western blot analysis of Mpst, Tst (thiosulfate sulfurtransferase), Cbs (cystathionine $\beta$-synthase), Cth (cystathionine $\gamma$-lyase), Gpx1 (glutathione peroxidase 1), and Gapdh (glyceraldehyde-3-phosphate dehydrogenase; as a loading control) in various mouse tissues. (B) Western blot analysis of the liver Mpst (and Tst) in wild-type (WT), heterozygous (Het), and homozygous (KO) Mpst mutant mice (1st-3rd lines) using the anti-mouse Mpst rabbit polyclonal antibody produced in this study. Relative amounts of Mpst protein was expressed as \% of the WT samples (mean $\pm \mathrm{SD} ; n=3$ each). (C) Hepatic expression of Tst, Cbs, Cth, Gpx1, and Gapdh using specific antibodies in WT, Het, and KO mice (1st-3rd lines). Relative expression of each protein was expressed as $\%$ of the WT samples (mean $\pm \mathrm{SD} ; n=3$ each). 


\section{A}

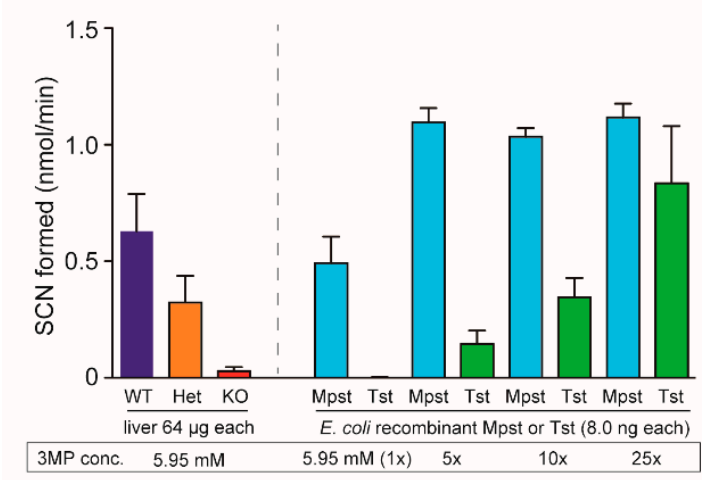

B

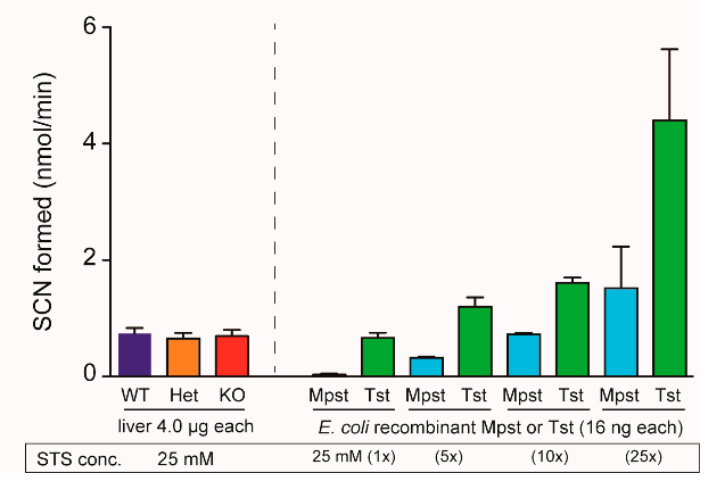

Figure 3. Mpst and Tst (rhodanese) enzyme activities from wild-type (WT), heterozygous (Het), and homozygous (KO) Mpst mutant mice liver homogenates, as well as mouse Mpst/Tst recombinant proteins. (A) Mpst enzyme assay. Although recombinant Tst protein displayed some 3-mercaptopyruvate (3-MP) degradation "Mpst" activities at substrate concentrations over $29.75 \mathrm{mM}$ $(5 \times)$, it did not show any activity at $5.95 \mathrm{mM}(1 \times)$. Under this condition, Mpst gene deletion abolished Mpst-specific activities in liver homogenates from KO mice. (B) Tst enzyme assay. Although recombinant Mpst protein displayed some sodium thiosulfate (STS) degradation "Tst" activities at $>125 \mathrm{mM}(5 \times)$, it did not show any activity at $25 \mathrm{mM}(1 \times)$. At this condition, Mpst gene deletion did not alter Tst-specific activities at any STS concentrations tested in liver homogenates from $\mathrm{KO}$ mice.

\subsection{Increased Urinary Excretion of 3-Mercaptolactate in Mpst-KO Mice}

Serum amino acid/thiol compound levels for all lines of Mpst-KO mice were indistinguishable from those of WT mice, which was in marked contrast to Cth mice; however, all Mpst-KO mice excreted 5.5-7.3 times the normal amount of 3-mercaptolactate (3-ML) in urine (Table 2). Though not significant, urinary (total) cysteine excretion tended to be higher in all Mpst-KO mice when comparted to WT mice (Table 2). These results suggest that Mpst-KO mice displayed MCDU. In contrast, serum biochemistry (albumin, alanine aminotransferase (ALT), aspartate aminotransferase (AST), blood urea nitrogen (BUN), creatine phosphokinase (CPK), creatinine (CRE), lactate dehydrogenase (LDH), total bilirubin (T-bilirubin), total protein (T-protein), uric acid (UA), and Thiobarbituric Acid Reactive Substances activity (TBARS)) did not reveal significant differences between WT and our Mpst-KO mice lines (Table 3), suggesting generally normal organ function, including the liver and kidney. 
Table 2. Concentrations of serum amino acid/thiol compounds, urinary thiol compounds, and liver glutathione in adult wild-type, Mpst (1st-3rd)-KO, Cth-KO, and Mpst (1st)/Cth-DKO mice.

\begin{tabular}{|c|c|c|c|c|c|c|}
\hline \multirow[b]{2}{*}{ Mice } & \multirow[b]{2}{*}{ WT (a) } & \multicolumn{3}{|c|}{ Mpst } & \multirow[b]{2}{*}{ Cth-KO (c) } & \multirow{2}{*}{$\begin{array}{l}\text { Mpst (1st)/Cth } \\
\text {-DKO (d) }\end{array}$} \\
\hline & & 1st KO (b) & 2nd KO & 3rd KO & & \\
\hline Serum $(\mu \mathrm{M})$ & $(n=10)$ & $(n=7)$ & $(n=7)$ & $(n=7)$ & $(n=5)$ & $(n=10)$ \\
\hline Ala & $479 \pm 128$ & $377 \pm 56$ & $439 \pm 79$ & $430 \pm 88$ & $574 \pm 239$ & $407 \pm 88$ \\
\hline Arg & $120 \pm 19^{c}$ & $104 \pm 23^{c}$ & $120 \pm 14$ & $113 \pm 24$ & $168 \pm 37 \mathrm{abd}$ & $146 \pm 26^{c}$ \\
\hline Asn/Asp & $6.28 \pm 2.66^{c}$ & $9.33 \pm 6.68^{c}$ & $17.4 \pm 9.4$ & $6.01 \pm 4.41$ & $28.1 \pm 17.8^{a b d}$ & $14.3 \pm 6.4^{\mathrm{c}}$ \\
\hline Gln & $807 \pm 135$ & $752 \pm 133$ & $762 \pm 74$ & $801 \pm 35$ & $935 \pm 172^{d}$ & $654 \pm 147^{c}$ \\
\hline Glu & $27.4 \pm 21.4^{c}$ & $26.1 \pm 17.9^{c}$ & $36.7 \pm 15.7$ & $19.9 \pm 8.1$ & $54.5 \pm 17.9^{a b}$ & $39.2 \pm 10.7$ \\
\hline Gly & $328 \pm 75$ & $291 \pm 38$ & $352 \pm 28$ & $306 \pm 64$ & $368 \pm 109$ & $345 \pm 49$ \\
\hline His & $42.0 \pm 24.5^{\mathrm{cd}}$ & $44.2 \pm 23.3^{\mathrm{cd}}$ & $85.1 \pm 19.1$ & $39.3 \pm 20$ & $131 \pm 58^{a b}$ & $90.4 \pm 10.4^{a b}$ \\
\hline Ile & $109 \pm 18$ & $106 \pm 18$ & $113 \pm 21$ & $105 \pm 14$ & $123 \pm 20$ & $106 \pm 20$ \\
\hline Leu & $159 \pm 21$ & $155 \pm 22$ & $170 \pm 26$ & $169 \pm 15$ & $196 \pm 11^{d}$ & $156 \pm 32^{c}$ \\
\hline Lys & $217 \pm 37$ & $226 \pm 42$ & $211 \pm 48$ & $255 \pm 33$ & $298 \pm 24$ & $184 \pm 44$ \\
\hline Met & $75.3 \pm 19.4$ & $69.9 \pm 16.7^{c}$ & $86.9 \pm 8.0$ & $67.6 \pm 11.0$ & $104 \pm 25^{b}$ & $96.6 \pm 22$ \\
\hline Phe & $95.6 \pm 26.9$ & $79.5 \pm 13.9$ & $86.0 \pm 7.0$ & $89.8 \pm 6.2$ & $106 \pm 23$ & $83.3 \pm 13.4$ \\
\hline Pro & $131 \pm 68$ & $91.2 \pm 26.7$ & $120 \pm 30$ & $94.5 \pm 28.4$ & $177 \pm 89$ & $135 \pm 36$ \\
\hline Ser & $145 \pm 58$ & $120 \pm 18$ & $143 \pm 18$ & $125 \pm 29$ & $175 \pm 62$ & $141 \pm 30$ \\
\hline Thr & $175 \pm 42$ & $151 \pm 35$ & $180 \pm 21$ & $163 \pm 45$ & $199 \pm 35$ & $194 \pm 43$ \\
\hline $\operatorname{Trp}$ & $71.2 \pm 17.1$ & $73.9 \pm 11.1$ & $61.5 \pm 16.5$ & $62.9 \pm 12.0$ & $69.9 \pm 9.6$ & $82.9 \pm 22.3$ \\
\hline Tyr & $94.8 \pm 32.0$ & $87.6 \pm 25.0$ & $110 \pm 18$ & $101 \pm 26$ & $99.2 \pm 58.9$ & $80.3 \pm 30.4$ \\
\hline Val & $242 \pm 58$ & $225 \pm 40^{c}$ & $253 \pm 29$ & $226 \pm 27$ & $304 \pm 43^{b}$ & $251 \pm 41$ \\
\hline Cystathionine & $44.1 \pm 19.7^{\mathrm{cd}}$ & $39.5 \pm 12.8^{\mathrm{cd}}$ & $56.2 \pm 12.6$ & $37.6 \pm 8.1$ & $124 \pm 15^{a b}$ & $133 \pm 32^{a b}$ \\
\hline Citrulline & $79.2 \pm 19.3^{\mathrm{cd}}$ & $63.0 \pm 15.2^{\mathrm{cd}}$ & $68.6 \pm 14.1$ & $67.2 \pm 12.7$ & $169 \pm 24^{\mathrm{ab}}$ & $135 \pm 34^{\mathrm{ab}}$ \\
\hline Ornithine & $42.1 \pm 10.9^{\mathrm{c}}$ & $35.1 \pm 10.2^{c}$ & $35.7 \pm 6.6$ & $43.0 \pm 16.2$ & $66.4 \pm 19.1^{\mathrm{ab}}$ & $49.5 \pm 13.8$ \\
\hline Taurine & $675 \pm 349$ & $491 \pm 136$ & $642 \pm 181$ & $514 \pm 88$ & $601 \pm 240$ & $664 \pm 235$ \\
\hline Total Cys & $319 \pm 40^{\mathrm{d}}$ & $322 \pm 52^{d}$ & $341 \pm 78$ & $315 \pm 32$ & $274 \pm 11$ & $261 \pm 51^{a b}$ \\
\hline Total Hcy & $5.78 \pm 1.22^{\mathrm{cd}}$ & $5.90 \pm 2.05^{\mathrm{cd}}$ & $5.58 \pm 0.77$ & $6.23 \pm 1.11$ & $83.6 \pm 18.6^{\mathrm{abd}}$ & $121 \pm 15^{a b c}$ \\
\hline Total GSH & $252 \pm 71^{\mathrm{cd}}$ & $230 \pm 141^{d}$ & $221 \pm 42$ & $224 \pm 37$ & $124 \pm 59^{a}$ & $107 \pm 42^{a b}$ \\
\hline Total Cys-Gly & $3.23 \pm 0.39^{b}$ & $4.43 \pm 0.59 \mathrm{ac}$ & $4.79 \pm 0.55$ & $3.93 \pm 0.39$ & $3.15 \pm 0.93^{b}$ & $3.87 \pm 0.86$ \\
\hline Total $\gamma$ Glu-Cys & $10.4 \pm 2.8$ & $13.2 \pm 4.0^{\mathrm{cd}}$ & $12.1 \pm 2.4$ & $8.37 \pm 1.94$ & $8.17 \pm 0.45^{b}$ & $8.32 \pm 2.16^{b}$ \\
\hline \multicolumn{7}{|c|}{ Urine ( $\mathrm{mmol} / \mathrm{mol}$ creatinine) } \\
\hline & $(n=10)$ & $(n=9)$ & $(n=7)$ & $(n=7)$ & $(n=6)$ & $(n=9)$ \\
\hline 3-ML & $10.4 \pm 2.0 \mathrm{bd}$ & $61.3 \pm 9.9$ acd & $57.4 \pm 29.4$ & $75.9 \pm 20.7$ & $16.9 \pm 3.2^{b d}$ & $91.2 \pm 21.0^{\mathrm{abc}}$ \\
\hline Total Cys & $156 \pm 28^{\mathrm{cd}}$ & $187 \pm 24^{\mathrm{cd}}$ & $222 \pm 50$ & $211 \pm 84$ & $624 \pm 272^{a b}$ & $601 \pm 115^{a b}$ \\
\hline Total Hcy & $7.32 \pm 2.66^{\mathrm{cd}}$ & $6.24 \pm 2.81^{\mathrm{cd}}$ & $6.15 \pm 1.11$ & $5.44 \pm 1.24$ & $169 \pm 51^{\mathrm{ab}}$ & $195 \pm 69^{a b}$ \\
\hline Total GSH & $2.00 \pm 1.28$ & $1.40 \pm 0.81$ & $2.31 \pm 1.09$ & $1.74 \pm 0.44$ & $2.67 \pm 1.84$ & $2.15 \pm 1.09$ \\
\hline Total Cys-Gly & $26.6 \pm 10.0^{\mathrm{cd}}$ & $25.4 \pm 7.1^{\mathrm{cd}}$ & $41.3 \pm 9.6$ & $32.4 \pm 12.0$ & $85.8 \pm 37.7^{a b}$ & $82.4 \pm 33.9^{a b}$ \\
\hline Total $\gamma$ Glu-Cys & $10.2 \pm 4.9^{\mathrm{cd}}$ & $9.45 \pm 3.70^{\mathrm{cd}}$ & $21.9 \pm 7.0$ & $14.3 \pm 3.5$ & $24.3 \pm 13.0^{\mathrm{ab}}$ & $26.8 \pm 7.7^{\mathrm{ab}}$ \\
\hline \multirow{2}{*}{\multicolumn{7}{|c|}{$\begin{array}{l}\text { Liver } \\
\text { Total GSH (nmol/mg protein; } n=5 \text { each) }\end{array}$}} \\
\hline & & & & & & \\
\hline \multicolumn{6}{|c|}{ GSSG/tGSH $(\% ; n=5$ each $)$} & $6.25 \pm 1.25^{\mathrm{ab}}$ \\
\hline & $4.04 \pm 0.48^{\mathrm{cd}}$ & $3.82 \pm 0.48^{\mathrm{cd}}$ & N.T. & N.T. & $5.42 \pm 0.62^{\mathrm{ab}}$ & $5.69 \pm 0.89^{a b}$ \\
\hline
\end{tabular}

Means \pm SD are presented ( $n$ : sample numbers). N.T., not tested. All parameters were similar in Mpst-KO mice lines; therefore, statistical analyses were done between WT, Mpst (1st)-KO, Cth-KO, and Mpst (1st)/Cth-DKO mice by one-way ANOVA with Tukey's multiple comparison test. Significant differences $(p<0.05)$ versus WT (a), Mpst (1st)-KO (b), Cth-KO (c), and Mpst (1st)/Cth-DKO mice (d). 
Table 3. Biochemical parameters in serum (and liver only for TBARS activity) for adult wild-type, Mpst (1st-3rd)-KO, Cth-KO, and Mpst (1st)/Cth-DKO mice.

\begin{tabular}{|c|c|c|c|c|c|c|}
\hline \multirow[b]{2}{*}{ Mice } & \multirow[b]{2}{*}{ WT (a) } & \multicolumn{3}{|c|}{ Mpst } & \multirow[b]{2}{*}{ Cth-KO (c) } & \multirow{2}{*}{$\begin{array}{l}\text { Mpst (1st)/Cth } \\
\text {-DKO (d) }\end{array}$} \\
\hline & & 1st KO (b) & 2nd KO & 3rd KO & & \\
\hline Serum & (8) & (7) & (7) & (7) & (5) & (10) \\
\hline Albumin (g/dL) & $2.10 \pm 0.12$ & $2.21 \pm 0.18^{\mathrm{d}}$ & $2.14 \pm 0.10$ & $2.19 \pm 0.20$ & $2.00 \pm 0.19$ & $1.97 \pm 0.16^{b}$ \\
\hline ALT (IU/L) & $17.5 \pm 10.8$ & $12.1 \pm 2.2^{\mathrm{d}}$ & $16.3 \pm 5.0$ & $16.0 \pm 5.3$ & $22.0 \pm 8.1$ & $29.2 \pm 12.6^{b}$ \\
\hline AST (IU/L) & $45.3 \pm 9.7$ & $39.6 \pm 12.3^{d}$ & $42.6 \pm 16.6$ & $42.1 \pm 14.0$ & $51.0 \pm 20.4$ & $75.2 \pm 40.4^{b}$ \\
\hline BUN (mg/dL) & $25.2 \pm 3.3$ & $25.4 \pm 3.4$ & $25.8 \pm 1.9$ & $26.8 \pm 5.3$ & $26.5 \pm 2.5$ & $26.5 \pm 3.1$ \\
\hline CPK (IU/L) & $394 \pm 110$ & $306 \pm 96^{d}$ & $448 \pm 222$ & $271 \pm 62$ & $351 \pm 84$ & $470 \pm 154^{b}$ \\
\hline CRE (mg/dL) & $<0.2$ & $<0.2$ & $<0.2$ & $<0.2$ & $<0.2$ & $<0.2$ \\
\hline $\mathrm{LDH}(\mathrm{IU} / \mathrm{L})$ & $173 \pm 48^{\mathrm{d}}$ & $157 \pm 16^{\mathrm{d}}$ & $282 \pm 93$ & $184 \pm 28$ & $225 \pm 54$ & $308 \pm 80^{a b}$ \\
\hline T-bilirubin (mg/dL) & $0.29 \pm 0.11$ & $0.30 \pm 0.12$ & $0.37 \pm 0.11$ & $0.27 \pm 0.08$ & $0.36 \pm 0.11$ & $0.35 \pm 0.07$ \\
\hline T-protein $(\mathrm{g} / \mathrm{dL})$ & $4.59 \pm 0.22^{\mathrm{d}}$ & $4.71 \pm 0.44^{\mathrm{d}}$ & $4.39 \pm 0.23$ & $4.63 \pm 0.49$ & $4.26 \pm 0.27$ & $4.13 \pm 0.23^{\mathrm{ab}}$ \\
\hline \multirow[t]{2}{*}{$\mathrm{UA}(\mathrm{mg} / \mathrm{dL})$} & $2.81 \pm 0.79 \mathrm{~cd}$ & $1.97 \pm 1.12$ & $1.74 \pm 0.60$ & $2.17 \pm 0.79$ & $1.60 \pm 0.39^{a}$ & $1.63 \pm 0.40^{\mathrm{a}}$ \\
\hline & (6) & (5) & & & (6) & (8) \\
\hline TBARS (nmol/mL) & $1.68 \pm 0.22$ & $1.68 \pm 0.23$ & N.T. & N.T. & $1.87 \pm 0.41$ & $1.50 \pm 0.17$ \\
\hline \multicolumn{7}{|l|}{ Liver } \\
\hline TBARS & (6) & (5) & & & (6) & (8) \\
\hline (nmol/ug protein) & $522 \pm 29^{d}$ & $546 \pm 77$ & N.T. & N.T. & $659 \pm 78$ & $702 \pm 169^{a}$ \\
\hline
\end{tabular}

Means \pm SD are presented ( $n$ : sample numbers). N.T., not tested. All parameters were similar in Mpst-KO mice lines; therefore, statistical analyses were done between WT, Mpst (1st)-KO, Cth-KO, and Mpst (1st)/Cth-DKO mice by one-way ANOVA with Tukey's multiple comparison test. Significant differences $(p<0.05)$ versus WT (a), Mpst (1st)-KO (b), Cth-KO (c), and Mpst (1st)/Cth-DKO mice (d).

\subsection{Generation of Mice Lacking Both Mpst and Cth}

We have previously generated Cth-KO mice [23] that require cyst(e)ine as an essential amino acid [23]; display increased vulnerability to cadmium/methyl mercury [24], paraquat [23], acetaminophen [25], dietary methionine [26], cardiac ischemia/reperfusion injury [27], unilateral ureteral obstruction-induced kidney fibrosis [28], and decreased contraction responses to oxytocin [29]. Physiologically, they appear normal under laboratory conditions and are fertile [23]. Therefore, we crossbred Mpst (1st)-KO mice with Cth-KO mice to generate Mpst/Cth-DKO mice. Mpst/Cth-DKO mice were obtained at the expected frequencies without sexual bias (Table 1) and developed normally with some slightly altered serum biochemical parameters for (hepatic) functions (e.g., albumin, ALT, AST, CPK, LDH, and T-protein) when compared to the Mpst (1st)-KO mice (Table 3). We observed that Cth gene deletion only affects Cth expression while Mpst gene deletion only affects Mpst expression in the liver when compared to Tst, Cbs, and Gpx1 (Figure 4). This indicates that compensatory expression of these proteins by Mpst/Cth deletion did not occur; although slight increases in hepatic TBARS activity were observed in Mpst/Cth-DKO mice (Table 3). Even breeding between Mpst/Cth-DKO males and females, as well as Mpst-het/Cth-KO males and females, could produce substantial numbers of pups although nearly halves of the breeding resulted in the deaths of all neonates, which is attributable to phenotypes (defective lactation) in Cth-KO mothers [29]. 
A

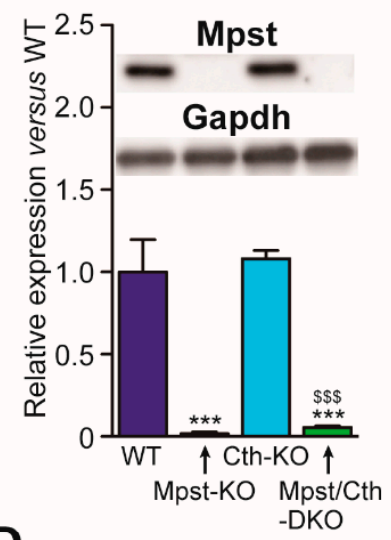

D

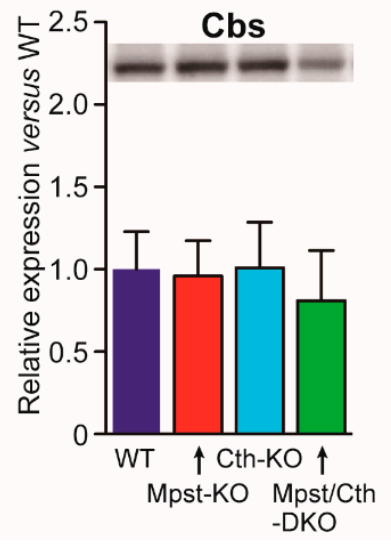

B

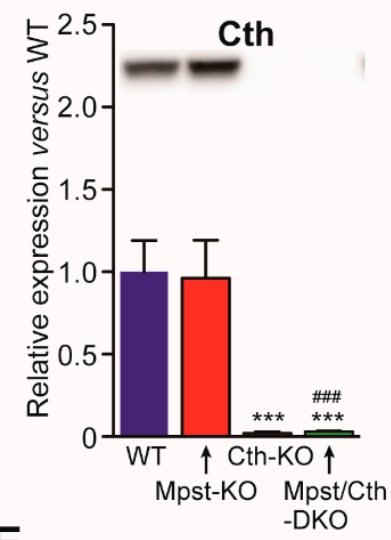

E

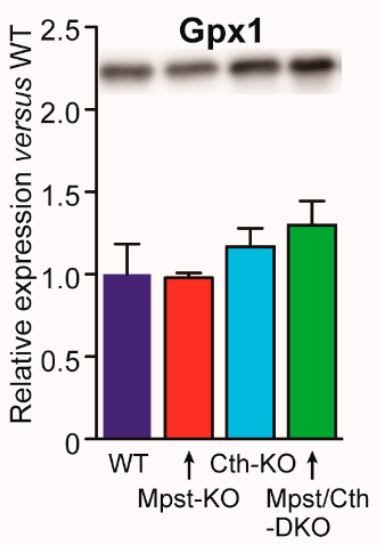

C

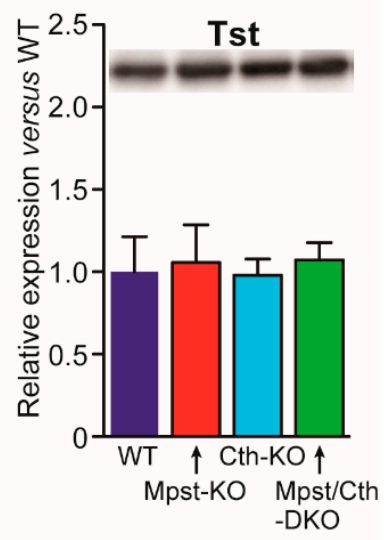

Figure 4. Hepatic expression of Mpst, Cth, Tst, Cbs, and Gpx1 in mice lacking Mpst, Cth, or both. Expression of Mpst (A), Cth (B), Tst (C), Cbs (D), and Gpx1 (E) in the livers of wild-type WT, Mpst (1st)-KO, Cth-KO, and Mpst (1st)/Cth-DKO mice was compared using Gapdh (A) as a loading control with that in WT liver as 1 . Significant differences were observed versus WT mice at ${ }^{* * *} p<0.001$; Mpst (1st)-KO mice at ${ }^{\# \#} p<0.001$; and Cth-KO mice at ${ }^{\$ \$} p<0.001(n=3)$.

\subsection{Enhanced PSA Response in Mpst-KO Mice}

$\mathrm{H}_{2} \mathrm{~S}$ has been shown to regulate various inflammatory responses [30,31], but its implications on anaphylaxis, "a serious generalized or systemic, allergic or hypersensitivity reaction that can be life-threatening or fatal [32,33]," remain unknown. Here we investigated dinitrophenyl (DNP)-conjugated human serum albumin (HSA)-induced PSA and passive cutaneous anaphylaxis (PCA) after pre-sensitization with anti-DNP IgE in WT, Mpst-KO, and Cth-KO mice as described in Materials and Methods. First, PSA was induced and changes in rectal temperature were followed. The hypothermic response associated with PSA was more pronounced in Mpst-KO mice compared to WT or Cth-KO mice; the maximum response was greater and the recovery was delayed (Figure 5A). Next, PCA was induced and differences in Evans blue dye extravasation between left (not pre-sensitized) and right ears (pre-sensitized with anti-DNP IgE) were evaluated. In contrast to PSA, PCA responses were similar in all mice (Figure 5B). 
A

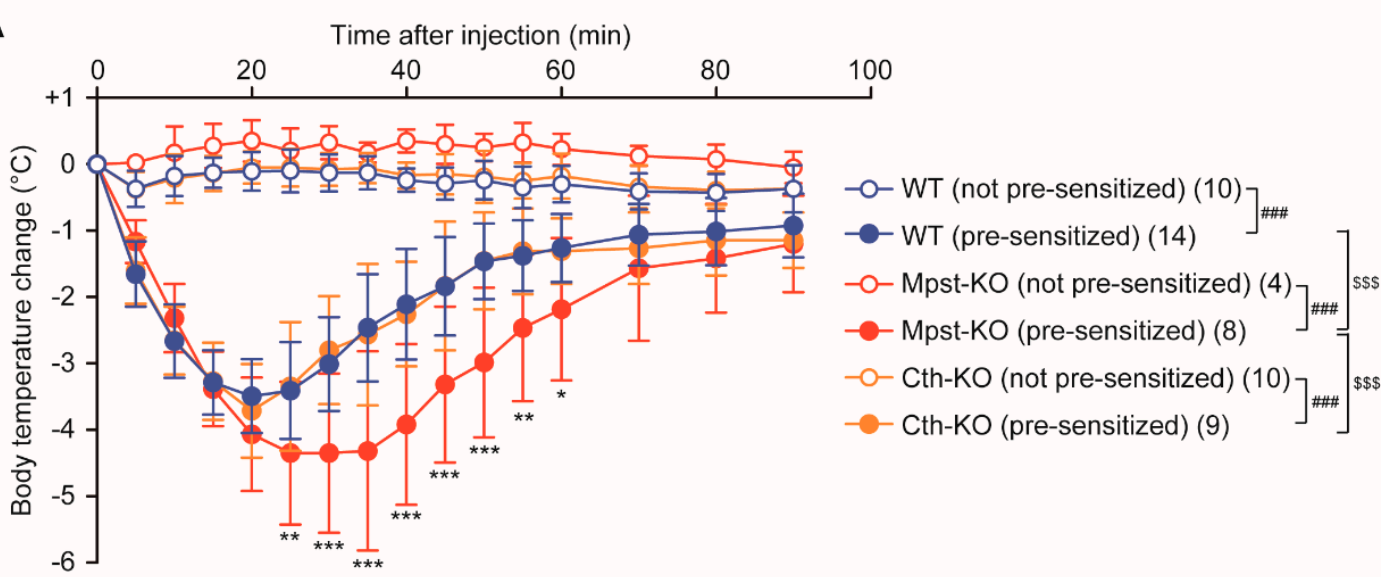

B

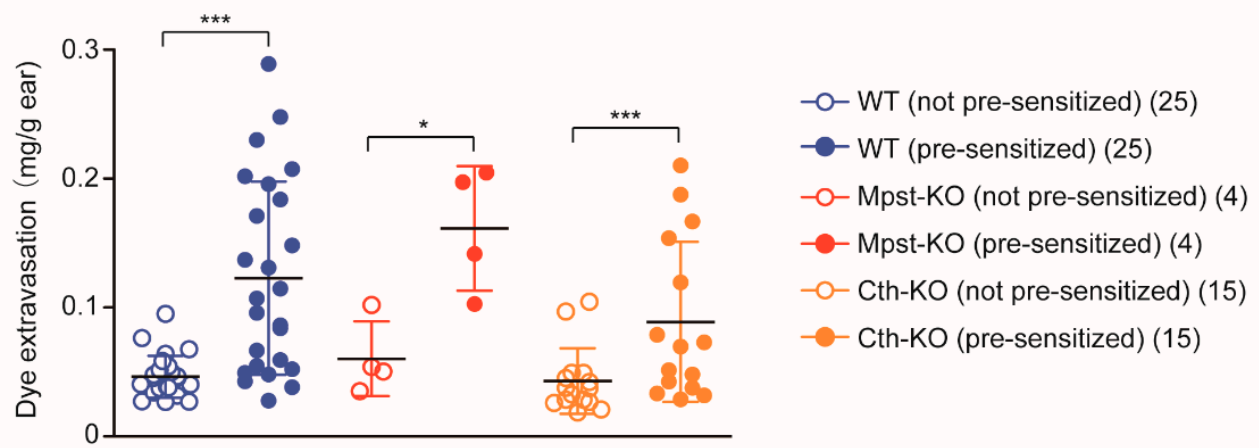

Figure 5. Hepatic Altered passive anaphylaxis (PSA but not PCA) in Mpst-KO mice. (A) Analysis of rectal temperatures in IgE-antigen-dependent PSA for WT, Mpst (1st)-KO, and Cth-KO mice after antigen challenge. Differences between pre-sensitized versus not pre-sensitized (vehicle alone) measurements were significant at ${ }^{\# \# \#} p<0.001$ as well as those between genotypes at ${ }^{\$ \$ \$} p<0.001$ in a two-way repeated-measured ANOVA with Bonferroni's multiple comparison test (Differences in each time point were significant at ${ }^{*} p<0.05,{ }^{* *} p<0.01$, and ${ }^{* * *} p<0.001$ ). (B) Analysis of ear edema in IgE-antigen-induced PCA in WT, Mpst-KO, and Cth-KO mice after antigen challenge. Differences in Evans blue dye extravasation between left (not pre-sensitized) and right ears (pre-sensitized with anti-DNP IgE) were evaluated. The ratio differences were significant ${ }^{*} p<0.05$ and ${ }^{* * *} p<0.001$, pre-sensitized versus not pre-sensitized) in ratio paired $t$-tests. Differences in the ratios were not significant between the genotypes in a one-way ANOVA with Tukey's multiple comparison test.

\section{Discussion}

MCDU has historically been attributed to MPST deficiency, but studies containing direct experimental evidence are lacking. We provide here the first direct evidence that Mpst deficiency in mice causes enhanced secretion of 3-ML in urine, a hallmark trait of MCDU (Table 2). Cysteine is first metabolized to 3-MP by AST. Following, 3-MP is metabolized to pyruvate by Mpst or to 3-ML by LDH; and thus, Mpst deletion could lead to enhanced 3-ML excretion to urine [11]. The quantitative detection of 3-mercaptolactate-cysteine disulfide in urine samples is currently underway. MCDU patients are rarely found; thus, previous investigations into 3-ML or 3-mercaptolactate-cysteine disulfide quantities in MCDU patient urine samples have yet to be performed. Therefore, we do not know whether the 5.5-7.3-fold level increase of 3-ML in urine (Table 2) is mirrored in MCDU patients.

Previously generated Mpst-KO mice exhibited increased anxiety-like behaviors associated with increased levels of serotonin and its major metabolite (5-hydroxyindoleacetic acid) in the prefrontal cortex and decreased levels of dopamine in the hippocampus [7]. Further, 2-3-fold increases in hepatic 
(mitochondrial) Tst expression have been observed [10]. Because Tst has some Mpst activity (that can metabolize 3-ML, Figure 3 and [9]), the potential overexpression of Tst may have an unexpected influence (e.g., alterations in neurotransmitter levels) on behavioral phenotypes in Mpst-KO mice. In this regard, our Mpst-KO mice lines have a great advantage over previous $\mathrm{KO}$ mice as hepatic Tst expression levels in our mice were comparable to that of WT mice (Figure 2B,C). Indeed, in our preliminary analyses, our Mpst-KO mice were free of any behavioral disorders common to all mutant lines such as increased anxiety (data not shown), which is in good agreement with a previous report that showed the absence of obvious physical and mental disabilities in two MCDU sisters (11 and 13 years old) [6]. Expression of Cbs, Cth, and Gpx1 were also comparable between all Mpst-KO mice and WT mice (Figure 2C). It should be noted that hepatic expression of Gpx1 (the anti-oxidant "selenoprotein") was not altered. This is important because Mpst may participate in selenium delivery to selenoproteins [34]. Accordingly, hepatic GSSG/tGSH ratios as well as TBARS activities (as the measures of oxidative stress/injury) in Mpst-KO mice were equivalent to those of WT mice (Table 2). The phenotypic differences between previous Mpst-KO mice and our Mpst-KO mice could be solely attributable to different Mpst gene deletion strategies as the mouse Tst gene is located near the Mpst gene (Figure 1A) and their genetic backgrounds are identical (C57BL/6J) [7].

In this study, we analyzed, for the first time, the systemic anaphylactic responses in Cth-KO and Mpst-KO mice and found greater PSA (but not PCA) responses in Mpst-KO mice (Figure 5). In anaphylaxis, mast cells and macrophages secrete various inflammatory mediators including histamine, platelet-activating factor, and cysteinyl leukotrienes; thereby eliciting vasodilation and increased vascular permeability which leads to hypothermia [35,36]. Passive anaphylactic responses originate from mast cells that are pre-sensitized with antigen-specific $\operatorname{IgE}$ antibodies [33]. Because vascular permeability levels (in PCA assay) were equivalent between Mpst-KO and WT mice, enhanced hypothermic responses (in PSA assay) are likely caused by abnormal vasodilation and autonomous thermoregulation rather than mast cell responses. A recent study demonstrated that the administration of propargylglycine into mice, a non-specific inhibitor of Cth, interferes with LPS (lipopolysaccharide)-induced and brown adipose tissue-mediated thermogenesis [37]; suggesting a possible role for $\mathrm{H}_{2} \mathrm{~S} / \mathrm{RSS}$ in general thermoregulation. Further studies are necessary to delineate the roles of Mpst/Cth and produced $\mathrm{H}_{2} \mathrm{~S} / \mathrm{RSS}$ in the thermoregulation.

Furthermore, we generated Mpst/Cth-DKO mice that develop normally (with generally normal serum biochemical parameters; Table 3) which are fertile. Although Cth is located upstream of Mpst in cysteine metabolism, both enzymes could provide active sulfane sulfur from cysteine in parallel for cyanide detoxification to thiocyanate [13]. General incidences for inherited diseases of amino acid metabolism by single gene deletion are estimated to be less than 1/250,000 [38]; thus, the occurrence of MCDU combined with "Cth-deficient" cystathioninuria should be extremely rare. Nonetheless, $\mathrm{Mpst} / \mathrm{Cth}-\mathrm{DKO}$ mice as well as Mpst-KO and Cth-KO mice are a very useful in vivo analytical tool, which contrasts with (semi-)lethal Cbs-KO [39,40] and Cars2-KO mice [22]. Mpst/Cth-DKO mice generally displayed the combined phenotypes of Mpst-KO (increased 3-ML levels in urine; Table 2) and Cth-KO mice (e.g., increased serum levels of His, cystathionine, citrulline, and total homocysteine (Hcy); increased urinary levels of total Cys, total Hcy, total cysteinylglycine (Cys-Gly), and total $\gamma$-glutamylcysteine ( $\gamma$ Glu-Cys); and reduced total glutathione (GSH) and increased GSSG/total GSH ratios in the liver) (Table 2). We previously reported that $\mathrm{Cth}-\mathrm{KO}$ mice look normal but display severe disorders upon various intervention, and our Mpst-KO mice and Mpst/Cth-DKO mice may be the similar. Although we are experiencing technical difficulties in obtaining sufficient numbers of $\mathrm{Cth}-\mathrm{KO}$ pups from Cth-KO mothers due to defective milk ejection [29] irrespective of coexisting Mpst mutations, further studies including the examination of Mpst/Cth-DKO mice for PSA/PCA alterations are needed.

In conclusion, we generated Mpst-KO mice as an animal model of MCDU and also Mpst/Cth-DKO mice as a useful tool for analyzing functions of $\mathrm{H}_{2} \mathrm{~S} / \mathrm{RSS}$ that both enzymes may produce in vivo. Moreover, we found a novel phenotype in Mpst-KO mice, the enhanced passive systemic anaphylaxis responses. Physiological significance and roles of Mpst are yet unknown and the further studies using 
those mice (e.g., molecular mechanisms of enhanced PSA in Mpst-KO mice) may provide new insight into the sulfur amino acid metabolism.

\section{Materials and Methods}

\subsection{Generation of Mpst (1st-3rd)-KO Mice}

Mpst-KO mice were generated using CRISPR/Cas9 technology from Setsurotech Inc. (Tokushima, Japan) on a C57BL/6J (C57BL/6JJcl; CLEA Japan, Tokyo, Japan) background as described previously [41] with some modifications. Briefly, in vitro fertilized zygotes $(\mathrm{C} 57 \mathrm{BL} / 6 \mathrm{~J} \times \mathrm{C} 57 \mathrm{BL} / 6 \mathrm{~J})$ were electroporated with $100 \mathrm{ng} / \mu \mathrm{L}$ recombinant Cas9 protein, $100 \mathrm{ng} / \mu \mathrm{L}$ tracrRNA, and $100 \mathrm{ng} / \mu \mathrm{L}$ of two crRNAs targeted upstream and downstream of the Mpst gene: Mpst crRNA upstream (u) (5'-ACGACCGCGGGCGCCAGGAG-3') and Mpst crRNA downstream (d) (5'-GCTGGGGAAACGGACTAATG-3'). Electroporated zygotes were transferred into the oviducts of pseudopregnant female ICR mice (Jcl:ICR, CLEA Japan), and a total of 14 mice were born on E19.5. Correct targeting/deletion was confirmed by PCR using forwarding (f) (5'-TGCTGGGCAAGGAATAGAGTG-3') and reverse (r) (5'-GCATATAAGGCCAGCACACG-3') primers that are located outside the targeted locus (Figure 1B). We sequenced the amplified PCR products for 1st, 2nd, and 3rd lines to confirm the deletion (Supplementary Figure S1). Routine tail DNA genotyping was done by three primer PCR reactions using primer 1 (5'-TTCCGCCACTGGCTGAATCAG-3'), primer 3 (5'-AGCTGGGCTACATCTTAGAGA-3'), and the reverse primer for the 1st and 3rd lines; and primer 2 (5'-ACGCACGTCGTGATCTACGAC G-3'), primer $4\left(5^{\prime}\right.$-CCTAGACCGGCTCAATGAATGT $\left.-3^{\prime}\right)$, and the reverse primer for the 2nd line (Figure 1C). Adult (8-18 weeks of age) male mice were used for our analyses. Sperms and embryos from all Mpst-KO mice lines were deposited in the Center for Animal Resources and Development (CARD) at Kumamoto University (Kumamoto, Japan; http://card.medic.kumamoto-u.ac.jp/card/english/index.html). All animal procedures conformed to the Guide for the Care and Use of Laboratory Animals, 8th Edition published by the US National Research Council and were approved by the Animal Care Committees of Showa Pharmaceutical University (No. P-2016-10 and P-2018-07; approval dates: 22 July 2016 and 12 April 2018, respectively).

\subsection{Preparation of Mpst and Tst Recombinant Proteins}

His-tagged murine Mpst (CS-Mm29353-B01-01; GenBank (NM_001162492.1)) and Tst (CS-Mm05875-B01-01; GenBank (NM_009437.4)) expression plasmids were purchased from GeneCopoeia (Rockville, MD, USA). The plasmids were transformed to Rosetta (DE3) pLysS Competent Cells (Novagen (Merck)). Single colonies were picked up from LB agar plates containing $100 \mu \mathrm{g} / \mathrm{mL}$ Ampicillin (Amp) and $34 \mu \mathrm{g} / \mathrm{mL}$ Chloramphenicol (CP), and placed into $75 \mathrm{~mL} \mathrm{LB}$ media $(100 \mu \mathrm{g} / \mathrm{mL}$ Amp and $34 \mu \mathrm{g} / \mathrm{mL} \mathrm{CP}$ ) for growth overnight at $37^{\circ} \mathrm{C} .50-\mathrm{mL}$ of the overnight culture was seeded into 1-L LB media $(100 \mu \mathrm{g} / \mathrm{mL} \mathrm{Amp})$ and grown at $30^{\circ} \mathrm{C}$ for $1.5 \mathrm{~h}$ and at $20^{\circ} \mathrm{C}$ for $2 \mathrm{~h}$. Following, isopropyl $\beta$-D-galactopyranoside (IPTG) was added (final $0.5 \mathrm{mM}$ ) and the culture was further grown at $20^{\circ} \mathrm{C}$ for $24 \mathrm{~h}$. Cells were then centrifuged and resuspended in $40 \mathrm{~mL}$ buffer $\mathrm{E}(20 \mathrm{mM}$ Tris- $\mathrm{HCl}(\mathrm{pH} 8.0)$, $150 \mathrm{mM} \mathrm{NaCl}, 1 \mathrm{mM}$ Tris(2-carboxyethyl)phosphine (TCEP) hydrochloride, and 10\% (v/v) glycerol) containing a Complete EDTA-free Protease Inhibitor Cocktail (Roche Diagnostics, Tokyo, Japan). Cells were then lysed by sonication and the soluble fraction was isolated by centrifugation $\left(12,000 \times g, 4{ }^{\circ} \mathrm{C}\right.$, $20 \mathrm{~min}$ ). Mpst and Tst recombinant proteins were affinity-purified with the TALON Metal Affinity Resins (Clontech) and a linear gradient of 10-100 mM imidazole. The pooled fraction was dialyzed twice against buffer $\mathrm{E}$ at $4{ }^{\circ} \mathrm{C}$ overnight using a Slide-A-Lyzer G2 Dialysis Cassette-20kDa cutoff (Thermo Fisher Scientific). The recombinant proteins were stored at $-80^{\circ} \mathrm{C}$ until use. 


\subsection{Rabbit Polyclonal Mpst Antibody Production}

A single Japanese white rabbit (3.0 kg female; Slc:JW/CSK (Japan SLC, Shizuoka, Japan)) was immunized with full-length mouse Mpst recombinant proteins using Freund's complete adjuvant four times (day $0(0.3 \mathrm{mg}), 28(0.2 \mathrm{mg}), 35(0.2 \mathrm{mg})$, and $42(0.2 \mathrm{mg}))$ and whole blood was collected at day 49. The blood was allowed to clot by leaving undisturbed at room temperature for $20 \mathrm{~min}$, and the clot was removed by centrifugation at $2000 \times \mathrm{g}$ for $10 \mathrm{~min}$ at $4{ }^{\circ} \mathrm{C}$. A total of $54 \mathrm{~mL}$ resulting supernatant (i.e., antiserum/polyclonal antibody) was obtained. Efficient antibody titers (O.D. > 3.0 at 1:16,000 dilution) were confirmed by ELISA (data not shown).

\subsection{Western Blot Analyses}

Each mouse tissue sample ( 100 mg) was homogenized in lysis buffer $(1 \mathrm{~mL}$ per $100 \mathrm{mg} ; 50 \mathrm{mM}$ Tris- $\mathrm{HCl}$ (pH 7.4), $150 \mathrm{mM} \mathrm{NaCl}, 1.0 \mathrm{mM}$ EDTA, $1 \%$ (w/v) Triton X-100, $0.1 \%$ (w/v) phenylmethylsulfonyl fluoride, and Complete EDTA-free Protease Inhibitor Cocktail) using a MicroSmash-100R homogenizing system (Tomy, Tokyo, Japan) and zirconia beads (4100 rpm, $\left.30 \mathrm{~s} \times 8,4{ }^{\circ} \mathrm{C}\right)$. Homogenates were centrifuged at $15,300 \times g$, at $4{ }^{\circ} \mathrm{C}$ for $20 \mathrm{~min}$. Supernatants were recentrifuged at $15,300 \times g$, at $4{ }^{\circ} \mathrm{C}$ for $30 \mathrm{~min}$. After heating $\left(95^{\circ} \mathrm{C}, 5 \mathrm{~min}\right)$ with the sample buffer, samples $(5 \mu \mathrm{g} / \mathrm{lane})$ were resolved on $10 \%$ or $12 \%$ pre-cast PAGE gels, and then transferred to the Immobilon PVDF membrane (Millipore) and subjected to western blotting. Mpst (and Tst as a cross-reactive protein) were detected with the above polyclonal antibody (1:10,000 in Can Get Signal immunostain Solution 1 (Toyobo)) and anti-rabbit IgG, HRP-linked whole Ab donkey antibody (GE Healthcare; 1:10,000 in Tris-Buffered Saline-Tween 20). Tst was detected with anti-human TST rabbit monoclonal antibody (Abcam ab1666625; 1:10,000) and anti-rabbit IgG, HRP-linked whole Ab donkey antibody (GE Healthcare; 1:10,000). Cbs was detected with anti-rat CBS rabbit polyclonal antibody ([42]; 1:5000) and anti-rabbit IgG, HRP-linked whole $\mathrm{Ab}$ donkey antibody $(1: 10,000)$. Cth was detected with anti-human CTH mouse monoclonal antibody (Abnova H00001491-M01; 1:5000) and mouse IgGK BP-HRP (mouse IgGk light chain binding protein-horseradish peroxidase; Santa Cruz sc-516102; 1:10,000). Gpx1 was detected with anti-human Gpx1/2 mouse monoclonal antibody (SantaCruz sc-133160; 1:10,000) and mouse IgGk BP-HRP $(1: 10,000)$. Gapdh was detected as a loading control with anti-GAPDH rabbit monoclonal antibody (Cell Signaling Technology (Danvers, MA, USA) \#2118; 1:10,000) and anti-rabbit IgG, HRP-linked whole Ab donkey antibody (GE Healthcare; 1:10,000). Chemiluminescence detection was performed using Chemi-Lumi One Ultra (Nacalai Tesque, Kyoto, Japan) and the ATTO WSE-6100 LuminoGraph I imager (ATTO, Tokyo, Japan).

\subsection{Mpst and Tst Activity Assays}

Mpst enzyme assays were performed using the substrate 3-MP as described previously [43,44], with some modifications. Liver homogenates (64 $\mathrm{g}$ each) or recombinant proteins (8.0 $\mathrm{ng}$ each) were incubated on 96-well microplates with $5.95(1 \times)-148.75 \mathrm{mM}(25 \times) 3-\mathrm{MP}, 175.6 \mathrm{mM}$ 2-amino-2-methylpropane-1,3-diol (AMPD), and $16.1 \mathrm{mM}$ potassium cyanide (KCN) in an $84 \mu \mathrm{L}$ mixture at $25{ }^{\circ} \mathrm{C}$ for $30 \mathrm{~min}$. The reaction was stopped by adding $20 \mu \mathrm{L}$ of $38 \%$ formaldehyde (final $6.67 \%$ ) and processed by adding $96 \mu \mathrm{L}$ of Goldstein's ferric nitrate reagent $\left(\mathrm{Fe}\left(\mathrm{NO}_{3}\right)_{3}+\mathrm{HNO}_{3}\right.$ $+\mathrm{H}_{2} \mathrm{O}$; [45]). Thiocyanate $\left(\mathrm{SCN}^{-}\right)$formation was determined by the measurement of absorbance at $460 \mathrm{~nm}$ using the Epoch 2 microplate spectrophotometer (BioTek/Agilent, Winooski, VT, USA). Tst enzyme assays were performed using the substrate thiosulfate as described previously [45] with some modifications. Liver homogenates $(4.0 \mu \mathrm{g}$ each) or recombinant proteins (16 ng each) were incubated with $25(1 \times)-625 \mathrm{mM}(25 \times)$ thiosulfate, $47.6 \mathrm{mM} \mathrm{KH}_{2} \mathrm{PO}_{4}$, and $71.4 \mathrm{mM} \mathrm{KCN}$ at $25^{\circ} \mathrm{C}$ for $30 \mathrm{~min}$ and processed similarly. Specific Mpst and Tst activities were obtained at substrate concentrations of $5.95 \mathrm{mM}$ (for 3MP) and $25 \mathrm{mM}$ (for thiosulfate), respectively. 


\subsection{Measurements of Amino Acid/Thiol Compound Levels and Biochemical Parameters}

Serum samples were analyzed for their amino acid concentrations using amino acid and thiol-derivatization fluorescent reagents (4-fluoro-7-nitrobenzofurazan (NBD-F) and 4-fluoro-7sulfobenzofurazan (SBD-F), respectively; Dojindo, Kumamoto, Japan) via a high-performance liquid chromatography (HPLC) as previously described [46] (Supplementary Figures S3-S5). Urine samples were analyzed for 3-ML and other thiol compounds via SBD-F and HPLC using a modified column/mobile phase system (to separate 3-ML and Cys-Gly peaks) as described previously [47,48] (Supplementary Figure S6). Briefly, SBD-F-labeled samples $(2 \mu \mathrm{L})$ were injected onto the InertSustain Amide column ( $3.0 \mathrm{~mm}$ ID $\times 150 \mathrm{~mm}$; GL Science, Tokyo, Japan), initialized at $10 \%$ A $(50 \mathrm{mM}$ ammonium formate ( $\mathrm{pH} 3.0$ ))/90\% B (acetonitrile) for $30 \mathrm{~min}$, followed by $25 \% \mathrm{~A} / 75 \% \mathrm{~B}$ for $15 \mathrm{~min}$, and finalized by $10 \%$ A/90\% B for 15 min, using an Agilent 1100 series chromatography workstation (Agilent, Santa Clara, CA, USA). The peaks in fluorescence (Ex. $385 \mathrm{~nm}$; Em. $515 \mathrm{~nm}$ ) were measured using an Agilent 1260 fluorescence detector. All amino acids/thiol compounds were identified based on their retention times; concentrations were calculated relative to the calibrated standard solutions. Serum biochemical parameters (albumin, ALT, AST, BUN, CPK, CRE, LDH, T-bilirubin, T-protein, and UA) were measured using a SpotChem EZ SP-4430 clinical analyzer (Arkray, Tokyo, Japan). Hepatic levels of oxidized glutathione (GSSG) and total glutathione (GSH+GSSG) were measured using the GSSG/GSH Quantification Kit (Dojindo, Kumamoto, Japan). GSSG/total glutathione percentages were calculated as a measure of oxidative status. TBARS assays were performed using TBARS assay kit from Cayman Chemicals (Ann Arbor, MI, USA) on serum and liver homogenates as per the manufacturer's instructions.

\subsection{PSA and PCA Assays}

PSA and PCA assays were performed as previously described [49]. For PSA assays, WT, Mpst-KO, and Cth-KO mice were intravenously administered with $3 \mu \mathrm{g}$ of anti-2,4-dinitrophenyl (DNP) mouse monoclonal IgE (SPE-7; Sigma-Aldrich) in $200 \mu \mathrm{L}$ PBS or PBS alone through tail veins. At $24 \mathrm{~h}$, the mice were challenged intravenously with $500 \mu \mathrm{g}$ of DNP-conjugated human serum albumin (DNP-HSA (filtered through 0.22- $\mu \mathrm{m}$ filter (Millipore) before use); Sigma-Aldrich) in $200 \mu \mathrm{L}$ PBS. After allergen challenge, rectal temperature was monitored every $5 \mathrm{~min}$ for $2 \mathrm{~h}$ using a BAT-12R microprobe thermometer equipped with a Mouse RET ISO Rectal Probe (Physitemp Instruments, Clifton, NJ, USA). For our PCA assays, mice were passively sensitized by intradermal injection with $10 \mathrm{ng}$ of anti-DNP mouse monoclonal IgE (SPE-7) in $20 \mu \mathrm{L}$ PBS. After $24 \mathrm{~h}$, the mice were challenged by intravenous injection (through tail veins) with $20 \mu \mathrm{g}$ of DNP-HSA in $200 \mu \mathrm{L}$ saline containing $1 \mathrm{mg}$ of Evans blue dye. Evans blue dye extravasation in the ear after $30 \mathrm{~min}$ was evaluated after sacrifice. Ears were removed and incubated at $37^{\circ} \mathrm{C}$ overnight in $500 \mu \mathrm{L}$ of $1 \mathrm{~N} \mathrm{KOH}$. The lysates were then mixed with $17.05 \mu \mathrm{L}$ of $44 \mathrm{~N}$ phosphoric acid and $975 \mu \mathrm{L}$ of acetone, and quantitative analysis of the dye in the extracts was performed within a linear range from 0.2 to $25 \mu \mathrm{g}$ measuring the absorbance at $620 \mathrm{~nm}$.

\subsection{Statistical Analyses}

Data were expressed as mean \pm SD (n: sample numbers). Statistical comparison was performed using Prizm 5 software (GraphPad, San Diego, USA). Two-way repeated-measured ANOVA with Bonferroni's multiple comparison test was used in PSA assays (Figure 5A) and ratio (pre-sensitized/not pre-sensitized) paired $t$-test was used in PCA assays (Figure 5B). One-way ANOVA with Tukey's multiple comparison tests were used in all other experiments. All $P$ values less than 0.05 denoted a significant difference.

Supplementary Materials: Supplementary Data can be found at http://www.mdpi.com/1422-0067/21/3/818/s1. Figure S1: Mouse Mpst gene and CRISPR/Cas9-mediated deletion of exon 2, Figure S2: Pre-incubation of anti-mouse Mpst rabbit polyclonal antibody with recombinant mouse Tst proteins abolishes 38-kDa (Tst) but not 33-kDa (Mpst) bands, Figure S3: Representative chromatograms in the measurements of free amino acids in serum samples, Figure S4: Representative chromatograms in the measurements of tryptophan in serum samples, 
Figure S5: Representative chromatograms in the measurements of thiol compounds in serum samples, Figure S6: Representative chromatograms in the measurements of 3-mercaptolactate in urine samples.

Author Contributions: All authors have read and agree to the published version of the manuscript. Conceptualization, N.A. and I.I.; methodology, N.A., T.M., M.M., U.S., C.S., R.T., A.H., W.K., S.K., Y.A., and I.I.; validation, N.A. and I.I.; formal analysis, N.A. and I.I.; investigation, N.A., T.M., M.M., U.S., C.S., R.T., A.H., W.K., S.K., Y.A., and I.I.; resources, N.A. and I.I.; writing—original draft preparation, I.I.; writing—review and editing, N.A. and I.I.; visualization, N.A. and I.I.; supervision, I.I.; project administration, N.A. and I.I.; funding acquisition, N.A. and I.I.

Funding: This work was partly supported by Grants-in-Aid for Scientific Research (17K08287 (to N.A.) and 16H05107 (to I.I.)) from the Japan Society for the Promotion of Science.

Acknowledgments: We thank undergraduate students, Saki Itoh, Haruna Katsura, Ryoka Hasegawa, Aya Shimonaga, Kazuki Terasawa, and Makoto Akahane (Showa Pharmaceutical University) for maintaining a breeding colony of mice.

Conflicts of Interest: The authors declare no conflict of interest.

\section{Abbreviations}

ALT

AST

BUN

Cars2

Cbs

CPK

CRE

Cth

DKO

DNP

Gpx1

GSH

GSSG

Hcy

$\mathrm{H}_{2} \mathrm{~S}$

$\mathrm{LDH}$

MCDU

3-ML

3-MP

Mpst

PCA

PSA

RSS

TBARS

Tst

UA

WT

\author{
Alanine aminotransferase \\ Aspartate aminotransferase \\ Blood urea nitrogen \\ Cysteinyl-tRNA synthetase 2 \\ Cystathionine $\beta$-synthase \\ Creatine phosphokinase \\ Creatinine \\ Cystathionine $\gamma$-lyas \\ Double knockout \\ 2,4-dinitrophenyl \\ Glutathione peroxidase 1 \\ Glutathione \\ Glutathione (oxidized form) \\ Homocysteine \\ Hydrogen sulfide \\ Lactate dehydrogenase \\ Mercaptolactate-cysteine disulfiduria \\ 3-Mercaptolactate \\ 3-Mercaptopyruvate \\ Mercaptopyruvate sulfurtransferase \\ Passive cutaneous anaphylaxis \\ Passive systemic anaphylaxis \\ Reactive sulfur species \\ Thiobarbituric acid reactive substances \\ Thiosulfate sulfurtransferase \\ Uric acid \\ Wild-type
}

\section{References}

1. Ampola, M.G.; Efron, M.L.; Bixby, E.M.; Meshorer, E. Mental deficiency and a new aminoaciduria. Am. J. Dis. Child 1969, 117, 66-70. [CrossRef] [PubMed]

2. Crawhall, J.C.; Parker, R.; Sneddon, W.; Young, E.P.; Ampola, M.G.; Efron, M.L.; Bixby, E.M. Beta mercaptolactate-cysteine disulfide: Analog of cystine in the urine of a mentally retarded patient. Science 1968, 160, 419-420. [CrossRef] [PubMed]

3. Crawhall, J.C.; Parker, R.; Sneddon, W.; Young, E.P. Beta-mercaptolactate-cysteine disulfide in the urine of a mentally retarded patient. Am. J. Dis. Child 1969, 117, 71-82. [PubMed]

4. Crawhall, J.C.; Bir, K.; Purkiss, P.; Stanbury, J.B. Sulfur amino acids as precursors of beta-mercaptolactatecysteine disulfide in human subjects. Biochem. Med. 1971, 5, 109-115. [CrossRef] 
5. Hannestad, U.; Martensson, J.; Sjodahl, R.; Sorbo, B. 3-mercaptolactate cysteine disulfiduria: Biochemical studies on affected and unaffected members of a family. Biochem. Med. 1981, 26, 106-114. [CrossRef]

6. Niederwiesler, A.; Giliberti, P.; Baerlocher, K. Beta-mercaptolactate cysteine disulfiduria in two normal sisters. Isolation and characterization of beta-mercaptolactate cysteine disulfide. Clin. Chim. Acta 1973, 43, 405-416. [CrossRef]

7. Nagahara, N.; Nagano, M.; Ito, T.; Shimamura, K.; Akimoto, T.; Suzuki, H. Antioxidant enzyme, 3-mercaptopyruvate sulfurtransferase-knockout mice exhibit increased anxiety-like behaviors: A model for human mercaptolactate-cysteine disulfiduria. Sci. Rep. 2013, 3, 1986. [CrossRef]

8. Nagahara, N. Catalytic site cysteines of thiol enzyme: Sulfurtransferases. J. Amino Acids 2011, $2011,709404$. [CrossRef]

9. Nagahara, N.; Okazaki, T.; Nishino, T. Cytosolic mercaptopyruvate sulfurtransferase is evolutionarily related to mitochondrial rhodanese. Striking similarity in active site amino acid sequence and the increase in the mercaptopyruvate sulfurtransferase activity of rhodanese by site-directed mutagenesis. J. Biol. Chem. 1995, $270,16230-16235$.

10. Nagahara, N.; Tanaka, M.; Tanaka, Y.; Ito, T. Novel Characterization of antioxidant enzyme, 3-mercaptopyruvate sulfurtransferase-knockout mice: Overexpression of the evolutionarily-related enzyme rhodanese. Antioxidants 2019, 8, 116. [CrossRef]

11. Ubuka, T.; Ohta, J.; Akagi, R.; Hosaki, Y.; Ishimoto, Y.; Kiguchi, S.; Ikeda, T.; Ishino, K. Metabolism ofL-cysteine via transamination pathway (3-mercaptopyruvate pathway). Amino Acids 1992, 3, 243-252. [CrossRef] [PubMed]

12. Nagahara, N.; Ito, T.; Minami, M. Mercaptopyruvate sulfurtransferase as a defense against cyanide toxication: Molecular properties and mode of detoxification. Histol. Histopathol. 1999, 14, 1277-1286. [PubMed]

13. Wrobel, M.; Jurkowska, H.; Sliwa, L.; Srebro, Z. Sulfurtransferases and cyanide detoxification in mouse liver, kidney, and brain. Toxicol. Mech. Methods 2004, 14, 331-337. [CrossRef] [PubMed]

14. Nagahara, N. Multiple role of 3-mercaptopyruvate sulfurtransferase: Antioxidative function, $\mathrm{H}_{2} \mathrm{~S}$ and polysulfide production and possible $\mathrm{SO}_{\mathrm{x}}$ production. Br. J. Pharmacol. 2018, 175, 577-589. [CrossRef]

15. Williams, R.A.; Kelly, S.M.; Mottram, J.C.; Coombs, G.H. 3-Mercaptopyruvate sulfurtransferase of Leishmania contains an unusual C-terminal extension and is involved in thioredoxin and antioxidant metabolism. J. Biol. Chem. 2003, 278, 1480-1486. [CrossRef]

16. Kimura, H. Signaling molecules: Hydrogen sulfide and polysulfide. Antioxid. Redox Signal. 2015, 22, 362-376. [CrossRef]

17. Shibuya, N.; Mikami, Y.; Kimura, Y.; Nagahara, N.; Kimura, H. Vascular endothelium expresses 3-mercaptopyruvate sulfurtransferase and produces hydrogen sulfide. J. Biochem. 2009, 146, 623-626. [CrossRef]

18. Shibuya, N.; Koike, S.; Tanaka, M.; Ishigami-Yuasa, M.; Kimura, Y.; Ogasawara, Y.; Fukui, K.; Nagahara, N.; Kimura, H. A novel pathway for the production of hydrogen sulfide from D-cysteine in mammalian cells. Nat. Commun. 2013, 4, 1366. [CrossRef]

19. Nagahara, N.; Koike, S.; Nirasawa, T.; Kimura, H.; Ogasawara, Y. Alternative pathway of $\mathrm{H}_{2} \mathrm{~S}$ and polysulfides production from sulfurated catalytic-cysteine of reaction intermediates of 3-mercaptopyruvate sulfurtransferase. Biochem. Biophys. Res. Commun. 2018, 496, 648-653. [CrossRef]

20. Kimura, Y.; Toyofuku, Y.; Koike, S.; Shibuya, N.; Nagahara, N.; Lefer, D.; Ogasawara, Y.; Kimura, H. Identification of $\mathrm{H}_{2} \mathrm{~S}_{3}$ and $\mathrm{H}_{2} \mathrm{~S}$ produced by 3-mercaptopyruvate sulfurtransferase in the brain. Sci. Rep. 2015, 5, 14774. [CrossRef]

21. Yadav, P.K.; Yamada, K.; Chiku, T.; Koutmos, M.; Banerjee, R. Structure and kinetic analysis of $\mathrm{H}_{2} \mathrm{~S}$ production by human mercaptopyruvate sulfurtransferase. J. Biol. Chem. 2013, 288, 20002-20013. [CrossRef] [PubMed]

22. Akaike, T.; Ida, T.; Wei, F.Y.; Nishida, M.; Kumagai, Y.; Alam, M.M.; Ihara, H.; Sawa, T.; Matsunaga, T.; Kasamatsu, S.; et al. Cysteinyl-tRNA synthetase governs cysteine polysulfidation and mitochondrial bioenergetics. Nat. Commun. 2017, 8, 1177. [CrossRef] [PubMed]

23. Ishii, I.; Akahoshi, N.; Yamada, H.; Nakano, S.; Izumi, T.; Suematsu, M. Cystathionine gamma-lyase-deficient mice require dietary cysteine to protect against acute lethal myopathy and oxidative injury. J. Biol. Chem. 2010, 285, 26358-26368. [CrossRef] [PubMed] 
24. Akiyama, M.; Unoki, T.; Shinkai, Y.; Ishii, I.; Ida, T.; Akaike, T.; Yamamoto, M.; Kumagai, Y. Environmental electrophile-mediated toxicity in mice lacking Nrf2, CSE, or both. Environ. Health Perspect. 2019, 127, 67002. [CrossRef] [PubMed]

25. Hagiya, Y.; Kamata, S.; Mitsuoka, S.; Okada, N.; Yoshida, S.; Yamamoto, J.; Ohkubo, R.; Abiko, Y.; Yamada, H.; Akahoshi, N.; et al. Hemizygosity of transsulfuration genes confers increased vulnerability against acetaminophen-induced hepatotoxicity in mice. Toxicol. Appl. Pharmacol. 2015, 282, 195-206. [CrossRef]

26. Yamada, H.; Akahoshi, N.; Kamata, S.; Hagiya, Y.; Hishiki, T.; Nagahata, Y.; Matsuura, T.; Takano, N.; Mori, M.; Ishizaki, Y.; et al. Methionine excess in diet induces acute lethal hepatitis in mice lacking cystathionine gamma-lyase, an animal model of cystathioninuria. Free Radic. Biol. Med. 2012, 52, 1716-1726. [CrossRef]

27. Nakano, S.; Ishii, I.; Shinmura, K.; Tamaki, K.; Hishiki, T.; Akahoshi, N.; Ida, T.; Nakanishi, T.; Kamata, S.; Kumagai, Y.; et al. Hyperhomocysteinemia abrogates fasting-induced cardioprotection against ischemia/reperfusion by limiting bioavailability of hydrogen sulfide anions. J. Mol. Med. 2015, 93, 879-889. [CrossRef]

28. Han, S.J.; Noh, M.R.; Jung, J.M.; Ishii, I.; Yoo, J.; Kim, J.I.; Park, K.M. Hydrogen sulfide-producing cystathionine gamma-lyase is critical in the progression of kidney fibrosis. Free Radic. Biol. Med. 2017, 112, 423-432. [CrossRef]

29. Akahoshi, N.; Handa, H.; Takemoto, R.; Kamata, S.; Yoshida, M.; Onaka, T.; Ishii, I. Preeclampsia-like features and partial lactation failure in mice lacking cystathionine gamma-lyase-an animal model of cystathioninuria. Int. J. Mol. Sci. 2019, 20, 3507. [CrossRef]

30. Bhatia, M. $\mathrm{H}_{2} \mathrm{~S}$ and Inflammation: An Overview. Handb. Exp. Pharmacol. 2015, 230, 165-180.

31. Flannigan, K.L.; Wallace, J.L. Hydrogen sulfide-based anti-inflammatory and chemopreventive therapies: An experimental approach. Curr. Pharm. Des. 2015, 21, 3012-3022. [CrossRef] [PubMed]

32. Simons, F.E.; Ardusso, L.R.; Bilo, M.B.; Cardona, V.; Ebisawa, M.; El-Gamal, Y.M.; Lieberman, P.; Lockey, R.F.; Muraro, A.; Roberts, G.; et al. International consensus on (ICON) anaphylaxis. World Allergy Organ. J. 2014, 7, 9. [CrossRef] [PubMed]

33. Reber, L.L.; Hernandez, J.D.; Galli, S.J. The pathophysiology of anaphylaxis. J. Allergy Clin. Immunol. 2017, 140, 335-348. [CrossRef] [PubMed]

34. Ogasawara, Y.; Lacourciere, G.M.; Ishii, K.; Stadtman, T.C. Characterization of potential selenium-binding proteins in the selenophosphate synthetase system. Proc. Natl. Acad. Sci. USA 2005, 102, 1012-1016. [CrossRef]

35. Balbino, B.; Sibilano, R.; Starkl, P.; Marichal, T.; Gaudenzio, N.; Karasuyama, H.; Bruhns, P.; Tsai, M.; Reber, L.L.; Galli, S.J. Pathways of immediate hypothermia and leukocyte infiltration in an adjuvant-free mouse model of anaphylaxis. J. Allergy Clin. Immunol. 2017, 139, 584-596. [CrossRef]

36. Makabe-Kobayashi, Y.; Hori, Y.; Adachi, T.; Ishigaki-Suzuki, S.; Kikuchi, Y.; Kagaya, Y.; Shirato, K.; Nagy, A.; Ujike, A.; Takai, T.; et al. The control effect of histamine on body temperature and respiratory function in IgE-dependent systemic anaphylaxis. J. Allergy Clin. Immunol. 2002, 110, 298-303. [CrossRef]

37. Soriano, R.N.; Braga, S.P.; Breder, J.S.C.; Batalhao, M.E.; Oliveira-Pelegrin, G.R.; Ferreira, L.F.R.; Rocha, M.J.A.; Carnio, E.C.; Branco, L.G.S. Endogenous peripheral hydrogen sulfide is propyretic: Its permissive role in brown adipose tissue thermogenesis in rats. Exp. Physiol. 2018, 103, 397-407. [CrossRef]

38. Harvey, R.A.; Ferrier, D.A. Lippincott's Illustrated Reviews: Biochemistry, 5th ed.; Woulters Kluwer-Lippincott Williams \& Wilkins: Philadelphia, PA, USA, 2011; pp. 261-276.

39. Watanabe, M.; Osada, J.; Aratani, Y.; Kluckman, K.; Reddick, R.; Malinow, M.R.; Maeda, N. Mice deficient in cystathionine beta-synthase: Animal models for mild and severe homocyst(e)inemia. Proc. Natl. Acad. Sci. USA 1995, 92, 1585-1589. [CrossRef]

40. Akahoshi, N.; Kobayashi, C.; Ishizaki, Y.; Izumi, T.; Himi, T.; Suematsu, M.; Ishii, I. Genetic background conversion ameliorates semi-lethality and permits behavioral analyses in cystathionine beta-synthase-deficient mice, an animal model for hyperhomocysteinemia. Hum. Mol. Genet. 2008, 17, 1994-2005. [CrossRef]

41. Hashimoto, M.; Yamashita, Y.; Takemoto, T. Electroporation of Cas9 protein/sgRNA into early pronuclear zygotes generates non-mosaic mutants in the mouse. Dev. Biol. 2016, 418, 1-9. [CrossRef]

42. Namekata, K.; Enokido, Y.; Ishii, I.; Nagai, Y.; Harada, T.; Kimura, H. Abnormal lipid metabolism in cystathionine beta-synthase-deficient mice, an animal model for hyperhomocysteinemia. J. Biol. Chem. 2004, 279, 52961-52969. [CrossRef] [PubMed] 
43. Jarabak, R.; Westley, J. 3-Mercaptopyruvate sulfurtransferase: Rapid equilibrium-ordered mechanism with cyanide as the acceptor substrate. Biochemistry 1980, 19, 900-904. [CrossRef] [PubMed]

44. Singh, P.; Rao, P.; Bhattacharya, R. Dose and time-dependent effects of cyanide on thiosulfate sulfurtransferase, 3-mercaptopyruvate sulfurtransferase, and cystathionine lambda-lyase activities. J. Biochem. Mol. Toxicol. 2013, 27, 499-507. [CrossRef] [PubMed]

45. Iciek, M.; Kotanska, M.; Knutelska, J.; Bednarski, M.; Zygmunt, M.; Kowalczyk-Pachel, D.; Bilska-Wilkosz, A.; Gorny, M.; Sokolowska-Jezewicz, M. The effect of $\mathrm{NaCl}$ on the level of reduced sulfur compounds in rat liver. Implications for blood pressure increase. Postepy Hig. Med. Dosw. 2017, 71, 564-576. [CrossRef]

46. Yamamoto, J.; Kamata, S.; Miura, A.; Nagata, T.; Kainuma, R.; Ishii, I. Differential adaptive responses to 1or 2-day fasting in various mouse tissues revealed by quantitative PCR analysis. FEBS Open Bio 2015, 5, 357-368. [CrossRef]

47. Isokawa, M.; Funatsu, T.; Tsunoda, M. Fast and simultaneous analysis of biothiols by high-performance liquid chromatography with fluorescence detection under hydrophilic interaction chromatography conditions. Analyst 2013, 138, 3802-3808. [CrossRef]

48. Isokawa, M.; Shimosawa, T.; Funatsu, T.; Tsunoda, M. Determination and characterization of total thiols in mouse serum samples using hydrophilic interaction liquid chromatography with fluorescence detection and mass spectrometry. J. Chromatogr. B Analyt. Technol. Biomed. Life Sci. 2016, 1019, 59-65. [CrossRef]

49. Taketomi, Y.; Ueno, N.; Kojima, T.; Sato, H.; Murase, R.; Yamamoto, K.; Tanaka, S.; Sakanaka, M.; Nakamura, M.; Nishito, Y.; et al. Mast cell maturation is driven via a group III phospholipase $\mathrm{A}_{2}$-prostaglandin $\mathrm{D}_{2}$-DP1 receptor paracrine axis. Nat. Immunol. 2013, 14, 554-563. [CrossRef]

(C) 2020 by the authors. Licensee MDPI, Basel, Switzerland. This article is an open access article distributed under the terms and conditions of the Creative Commons Attribution (CC BY) license (http://creativecommons.org/licenses/by/4.0/). 